Portland State University

PDXScholar

Dissertations and Theses

Dissertations and Theses

Summer 8-14-2019

\title{
How Does Wasta Bolster Regimes? The Case of Tunisia
}

Issrar Chamekh

Portland State University

Follow this and additional works at: https://pdxscholar.library.pdx.edu/open_access_etds

Part of the Near and Middle Eastern Studies Commons, and the Political Science Commons Let us know how access to this document benefits you.

Recommended Citation

Chamekh, Issrar, "How Does Wasta Bolster Regimes? The Case of Tunisia" (2019). Dissertations and Theses. Paper 5385.

https://doi.org/10.15760/etd.7258

This Thesis is brought to you for free and open access. It has been accepted for inclusion in Dissertations and Theses by an authorized administrator of PDXScholar. Please contact us if we can make this document more accessible: pdxscholar@pdx.edu. 


\title{
How Does Wasta Bolster Regimes?
}

The Case of Tunisia

\author{
by \\ Issrar Chamekh
}

A thesis submitted in partial fulfillment of the requirements for the degree of

\author{
Master of Science \\ in \\ Political Science
}

Thesis Committee:

Lindsay Benstead, Chair

Melody Ellis Valdini

Richard Clucas

Portland State University

2019 
(C) 2019 Issrar Chamekh 


\begin{abstract}
This paper aims to highlight the impact of democratization on wasta by examining the everyday performance of wasta, or the use of connections and informal networks to acquire services. Despite its widespread use, I find that it is understudied as an explanatory variable in the literature on democratization and authoritarianism in the Middle East and North Africa, with Tunisia as a case study. In this paper, I argue that wasta can potentially have a consolidating effect on regimes. I examine the ways that wasta is encoded in everyday language. Using literature from Pragmatics, specifically Goffman's dramaturgical model, I find that Tunisians' discursive world view reveals the power dynamics that underly the performance of wasta. I close with a research agenda that examines common approaches to studying wasta and how they can be improved by integrating an ethnographic lens.
\end{abstract}




\section{Dedication}

I dedicate my work to the protesters who were shot down for demanding "dignity, freedom, social justice" and inspiring me in the process.

I also dedicate it to the disappeared whose families are still searching for. May their families find peace in seeing a new Tunisia that is kinder and more just. 


\section{Acknowledgements}

I want to thank the Fulbright Program for their financial support these past two years. Thank you to Emmanuel Pimentel and Zerlina Bartholomew for their patience.

I also want to thank Dr. Lindsay Benstead for her calm confidence and Dr. Melody Ellis Valdini for her seemingly endless patience and compassion. Thank you to my family for their constant sacrifice and for reminding me where home is; and to Gaya, for being the sweetest person in the world. Last but not least, thank you to Mavis the Basset, the most gentle and cuddly doggy friend on the face of the earth. 
Table of Contents

Abstract $\quad$ i

Dedication $\quad$ ii

Acknowledgements $\quad$ iii

List of Tables $\quad$ vi

List of Figures vii

Abbreviations viii

Part One 1

Introduction 1

What is Wasta? 4

Why Should we Care? $\quad 6$

Wasta in the Literature $\quad 7$

Wasta and Political Clientelism $\quad 7$

Clients' Point of View 8

The Case of Tunisia 9

Methodology and Limitations 10

Part Two 12

The Colonial and the Postcolonial 12

The Evolution of Wasta 14

Is Wasta a Form of Corruption? 15

Linguistic Encoding of Wasta 15

$\begin{array}{ll}\text { Announcement of Wasta } & 17\end{array}$

$\begin{array}{ll}\text { Hierarchy } & 17\end{array}$

Reputation 18

$\begin{array}{ll}\text { Party Politics and Wasta } & 20\end{array}$

The Political Economy of Wasta 20

Change and Continuity 21

Wasta After 2011

$\begin{array}{ll}\text { Part Three } & 25\end{array}$ 
Research Agenda 25

Surveys and Public Opinion 25

Wasta and Political Ethnography 28

$\begin{array}{ll}\text { Conclusion } & 29\end{array}$

Bibliography 31 


\section{List of Tables}

Table 1. Expressions in Tunisian Derja 


\section{List of Figures}

Figure 1. willis from tunis (2018) 3

Figure 2. Common wasta scenario 19

Figure 3. Questions from 226 and 227 from Wave I 26

Figure 4. Question 506 from Wave I 26

Figure 5. Question q213 from Wave IV 27 


\begin{abstract}
Abbreviations $^{1}$
ANC: National Constituent Assembly

IVD: Truth and Dignity Commission

RCD: Democratic Constitutional Rally

SNFSI: National Syndicate of Internal Security Forces

UNDP: United Nations Development Program
\end{abstract}

${ }^{1}$ As is common in Tunisia and the Maghreb in general, institutions are often referred to by their French acronyms. 


\title{
Part One
}

\author{
Introduction
}

He who gave his word to someone, also gave them his life. ${ }^{2}$

Do like your neighbor or move out. ${ }^{3}$

Tunisian proverbs

In late December 2010, the Tunisian people toppled a 23-year regime who had made any form of dissent, private or public, exceedingly dangerous. Strict censorship governed public spaces, with complex structures put in place to control literary production, the media, and other realms of life. In other words, collective imagination was tightly surveilled and policed ${ }^{4}$. However, the large-scale protests that broke out in late December saw thousands of people take to the street and defy police violence to demand "dignity, freedom, social justice" ${ }^{\prime 5}$ Eight years later, Tunisia’s democratic transition became one of its biggest selling points: successful election of the National Constituent Assembly (ANC) that passed a new constitution considered the most progressive in the region, free and fair democratic elections of a president and a parliament, and the country's first ever local elections of municipal councils in each of the country's 24 governorates ${ }^{6}$. However, how much has really changed in people's everyday lives? Of the everyday processes that have survived the democratic

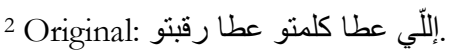

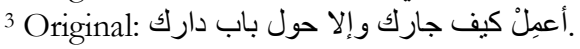

4 This paper's main case study is Tunisia, which is my only country of citizenship and where I lived until 2017. My own experiences with authoritarianism, wasta, and protests will heavily inform my knowledge of this case study.

${ }^{5}$ Many of their chants were then picked up by other states in the region, becoming emblems of freedom of speech.

${ }^{6}$ Municipal Council members used to be appointed rather than elected.
} 
overhaul, what can their study tell us about the opportunities and obstacles that social movements are faced with in the future?

'willis from tunis' [sic] is the nom de plume of Tunisian cartoonist Nadia Khiari whose political satire has become popular ever since the first 2011 protests broke out. Her protagonist, Willis “The Cat of the Revolution” (Grillmeier 2018) is a humanoid character that the artist uses to voice her critique of authoritarianism, social inequality, and political absurdities. One of Khiari's recent cartoons is worth examining as it nicely informs the rest of this paper.

The October 2018 piece has two scenes (willis from tunis 2018). The first reveals Willis, paws in the air and lips tightly muffling a cry as a tear escapes his eye and a policeman's black boot pins his head to the ground with the caption "Avant la révolution, c'était $c ̧ a$ " ("Before the Revolution, we had this"). The same scene is repeated again, except this time around Willis is crying audibly in pain, "Aaaaïize" under the caption "Mais aujourd'bui, beureusement, on a la liberté d'expression?' (“But luckily today we have freedom of expression!”). This visual representation juxtaposes change and continuity to reveal a striking reality about life in Tunisia after the political transition: newfound freedoms, like freedom of expression and freedom to protest, but within an immutable police state. 
Figure 1. willis from tunis (2018)
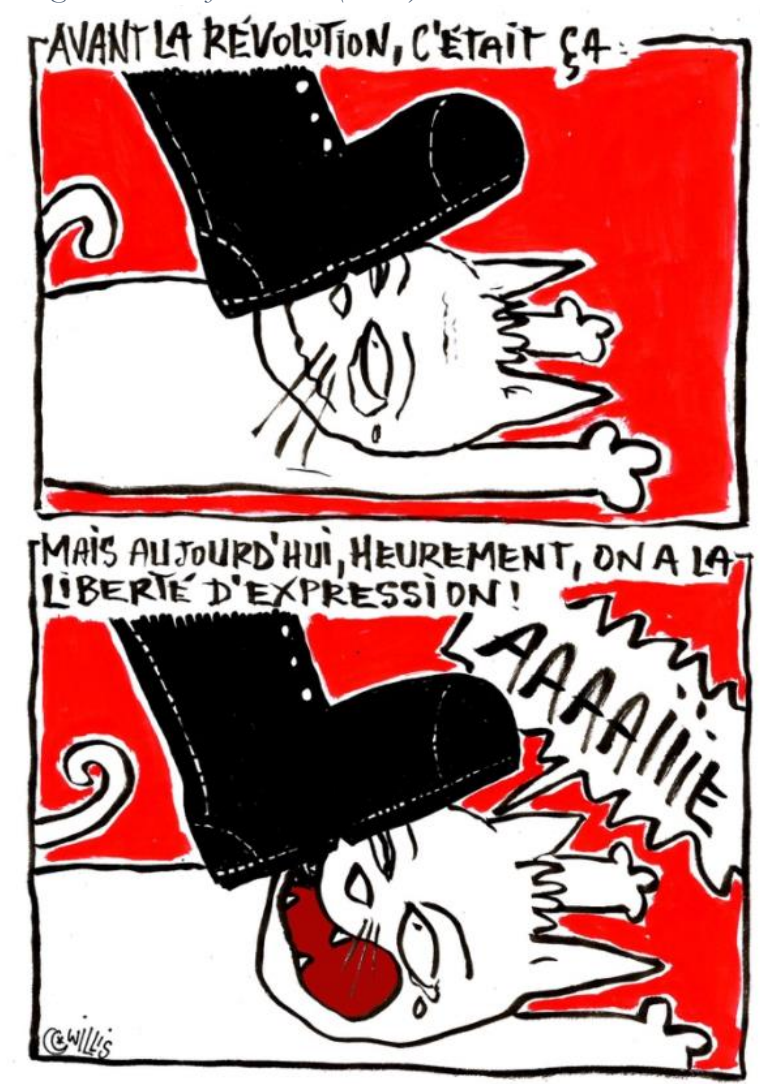

There have been constant reports of use of excessive force against civilians and death under police custody due to torture (e.g. Chebaane 2019). Kimball (2019) writes that in light of the country's democratic opening, the police created their first union, the National Syndicate of Internal Security Forces, SNFSI (2019). While this is justified as a way for the police to improve their working conditions and security, many Tunisians are skeptical and think that this is one of the ways that the police are trying to cover their tracks and their history of abuse and continued impunity (Kimball 2019).

In 2014, the then-president Moncef Marzouki launched the Truth and Dignity Commission (the IVD) to investigate state violations since 1955 (UNDP 2014). Fida 
Hammami, a Tunisian researcher at Amnesty International, reports that "police unions have also been very hostile to the IVD [which] summons officers that might be involved in cases they're investigating. [The unions] have encouraged their members not to cooperate" (Kimball 2019). The police state, however, is not the only aspect of pre-2011 Tunisia that has remained largely intact. This paper follows a bottom-up approach by centering citizens' interactions with the state and its institutions, specifically in the way that they approach service provisions and acquiring benefits. This means looking at the most common way that services are provided: connections, or wasta. As will be argued later, violence is not the only way that obedience is enforced. I conclude that wasta is one of the ways that the state exercises power even when it doesn't do so through physical threat.

\section{What is Wasta?}

Hans Wehr (1993) defines wasta as "mediator, intermediary, medium, expedient" (1067). It was originally used to describe those who mediate conflict at the family, communal, or wider tribal level (Lackner 2016). Also referred to as 'vitamin waw ${ }^{57}$, wasta has no exact translation in English which explains the wide use of the Arabic loan word. Lackner (2016) lists the following terms that are often used to refer to wasta in the Anglophone world, "patronage, nepotism, touting, brokerage, rent-seeking, clientelism and cronyism, as well as gatekeepers and expediters" (35). However, as she rightly notes, this lack of a direct equivalent can potentially reinforce negative interpretations of the practice of wasta. In this paper, I argue that this actually contributes to several issues.

\footnotetext{
${ }^{7}$ This is used mostly in Levantine dialects of Arabic, especially Jordan and Palestine. 'Waw' is the transliteration of the letter 9 , or ' $w$ ', in reference to the first letter of the word 'wasta'.
} 
Wasta is too often seen as a 'form' of corruption (Anderson 2016; Sadi 2017;

Ramady 2017). This isn't necessarily true, as oftentimes no law is technically being broken (Doughan 2017). However, the implications of this lack of conceptual clarity involve inadequate policy responses that overemphasize legal reform at the expense of distributive justice (Doughan 2017).

For the purposes of this paper, I use Lackner's (2016) definition which captures how ordinary people understand wasta "the mediator uses his influence with a state or private provider to assist the other party in obtaining something which she/he may or may not be entitled to" (35). I add that wasta is often used to obtain that which the party is very much entitled to, but bureaucratic obstacles would might make too costly (money and time-wise). Doughan (2017) notes that wasta is not unique to the Middle East and North Africa. It has equivalents like blat in Russia (Ledeneva 1998), raccomandarione in Italy (Zinn 2001), pulling strings in the United States, protektria in Israel (Danet 1989), Beziehungen in Germany, and guanxi in China (Nuijten and Anders 2007). In the Maghreb, the French term piston is much more common than the term 'wasta', but they are direct equivalents.

Understood as such, wasta takes a much bigger significance than its more restricted applications elections or parliamentary politics. It can be applied to other areas as well, such as labor politics and the role of labor unions, banking and debt, and finally, bureaucratic services (e.g. renewing passports, IDs, obtaining birth certificates, construction licenses, access to public hospitals, etc.). I argue that these areas are central to the negotiation of power and citizenship, in authoritarian regimes and during democratization periods. ${ }^{8}$

\footnotetext{
${ }^{8}$ My discussion of wasta applies to administrations and the banking sector. I only suggest ways that future research can examine labor unions, because of logistic limitations that have to do with unavailability of data at this stage.
} 
Why Should we Care?

The significance of this issue goes beyond a mere intellectual exercise. The Middle East and North Africa, the Arab World, or the Near East, etc. is a region that is hardly afforded any cultural and political subtleties in the media and so in people's imagination. It's easy to stereotype and categorize such a diverse and dynamic region when researchers unsarcastically use terms such as "Arab corruption” (Warf 2018) to essentialize the so-called "Arab World" implying that some inherent trait makes their brand of corruption different from any other around the world. This leads to using metaphors of "endemic" infectious diseases that need a "war" to be "eradicated" (Yerkes and Muasher 2017).

This paper seeks to disambiguate one of the most widespread phenomena in the Middle East and North Africa without further contributing to the 'othering' of a whole region. By historicizing wasta, we can understand that though it is 'informal', it has its internal rules and structure. Seen as a byproduct of the hybridization of colonial bureaucracy and a tribal, kin-based social infrastructure, wasta stands out not as an extra-legal practice but a natural evolution of colonial structures.

Differentiating wasta from corruption does not seek to attribute a positive value judgement to wasta. It contributes to understanding the structures that ordinary people operate in. It also provides a better understanding of how citizens view their representatives and their political role. In other words, this paper's ultimate goal is to fill the gap that the literature on corruption and political clientelism have neglected: democratization does not solve the structural inequalities in which wasta thrives. 
Wasta in the Literature

Wasta and Political Clientelism

Political clientelism is defined by Stokes (2011) as "the proffering of material goods in return for electoral support, where the criterion of distribution that the patron uses is simply: did you (will you) support me?" (2). This is clearly one of the ways that wasta can be understood-political wasta. The literature on political clientelism is vast and extremely rich, especially as it pertains to Latin America whose electoral politics rely heavily on vote buying and brokerage (Stokes 2011; Kitschelt and Wilkinson 2007). This relationship typically involves an unequal exchange, which is both voluntary and exploitative (Stokes 2011). Early studies have established that the "cement" in this paradoxical relationship is a moral norm of reciprocity which prevents defection (Gouldner 1960). This applies to everyday wasta as well. How different are wasta and political clientelism?

When it comes to the Middle East and North Africa, studies on political clientelism are few and far between. As widespread as wasta is throughout the region, this in not necessarily reflected in the literature on the Middle East and North Africa. Most works look at elite level wasta, or political clientelism. For example, in her seminal work, Lust (2009) argues that in authoritarian regimes, elections are hardly ever about reimagining the rules of the game. Legislative elections in countries such as Algeria, Tunisia, and Egypt were held not for the purpose of negotiating democratization. All parties were aware that "elections are best thought of as competitions over access to state resources, or 'competitive clientelism,' and the candidates and voters alike recognize this" (124). This is a significant observation, especially as Lust's arguments applies to MPs who enjoy invaluable perks like political immunity, allowing them to abuse resources and connections in complete impunity in the 
absence of accountability mechanisms. It also explains why parties go through the trouble of becoming potential targets of autocrats when they are already aware that their cause is lost. Regardless, overemphasizing elite-level wasta draws attention away from “ordinary” wasta that happens within the bounds of the law, but which has far-reaching consequences. This view "from below" is needed to understand the viewpoint of "clients" who are seeking services they may not be entitled to or would be too costly (financially and time-wise) were they to follow standard procedure without the prior knowledge of a "patron" who would facilitate the whole process.

\section{Clients' Point of View}

The bulk of seminal research on clientelism prioritizes elite perspectives (Benstead 2016; Blaydes 2008; Gans-Morse, Mazzuca, and Nichter 2014; Hachemaoui 2013; Liddell 2010; Lust 2009; Piattoni 2001; Richter 2007). Clients' perspective has received more attention recently in Political Science, however works in other fields such as Sociology and Anthropology have already tried to piece out why and how citizens (especially poor people) choose to engage in clientelistic relationships (Auyero 1999, 2000, 2001). Beyond political clientelism and vote-buying, there is hardly any research on "everyday" wasta in the Middle East and North Africa unless it is cast within a discourse of 'fighting corruption" or examining political clientelism.

More recently, some works have started looking at clients' perspectives in clientelistic regimes. However, this is still restricted to electoral politics (Pellicer et al. 2017; Pellicer et al. 2018) and studies are still surprisingly scarce. Again, Political Science remains behind on

\footnotetext{
${ }^{9}$ To the best of my knowledge.
} 
looking at clientelism "from below". As I argue later in this paper, this is due to a lack of methodological diversity which overemphasizes elite-level analysis at the expense of microlevel interactions.

The small literature that deals with wasta per se largely looks at it in the GCC as a problem of leadership and business management (Berger et al. 2015; Velez-Calle, RobledoArdila, and Rodriguez-Rios 2015; Amin Mohamed and Hamdy 2008; Smith et al. 2012; Loewe et al. 2007; Al-Ramahi 2008). While these insights are valuable for understanding the climate in which access to employment opportunities takes place, they fall short of explaining how the often well-connected, but unqualified, job candidates contribute to reproducing the power dynamics upon which authoritarian regimes are built. Studies that look at social categories such as class and gender within wasta are rare, one of which is Bailey (2012) who uses focus groups with Emirati women to argue that despite religious arguments against wasta ${ }^{10}$, gender and class intersect to doubly marginalize women from access to opportunities. This is an example of the "dark" side of wasta-those who are deprived of patriarchal and class privilege.

\section{The Case of Tunisia}

The surprising lack of work on wasta also applies to the case study at hand, Tunisia. The fall of Ben Ali's regime opened the way for research that would not have been possible pre-2011. Political Islam has been a popular topic among researchers, asking questions about the compatibility of Islam and democracy (Kadlec 2016; Schwedler 2011; Cavatorta and

\footnotetext{
${ }^{10}$ In fact, Amin Mohamed and Hamdy (2008) have surveyed religious texts and argued that when people have negative attitudes against wasta, it is due to Islam's condemnation of corruption.
} 
Merone 2013; Lounnas 2016; Ghannouchi 2016; Dalmasso and Cavatorta 2013; Hamid 2018; Rohr 2011; Ounissi and Marks 2016; Wegner and Cavatorta 2018; Wolf 2017) and the future of gender in an Islamic democracy (de Silva de Alwis, Mnasri, and Ward 2017; Cordall and Mahmood 2017; Sadiqi 2016; Moghadam 2016; Muhanna-Matar 2015; Khalil 2014; Badran 2013; Pruzan-Jørgensen 2012; Marks 2012; Gray 2012; Marks 2011; Coleman 2011). To be clear, these research questions are of utmost importance because of the fragility of the Tunisian transition and the need to investigate issues that had been impossible to raise before because it was too dangerous, people were too afraid to speak, or politicians were extremely untrustworthy because of their loyalty to the ruling party, the RCD (the Democratic Constitutional Rally). However, the trend is clear: everyday citizens' experiences of the transition are understudied.

Because of this gap in the literature, this paper aims to expand the literature on democratization and everyday politics by centering the perception of those seeking wasta as well as those providing it. As I will explain, outside of vote-buying, wasta in Tunisia is oftentimes reciprocal. The most precarious wasta scenario is not simply when someone has no connections to get around, but when they do not signal to their wasta that they can repay the favor (sooner or later).

\section{Methodology and Limitations}

In addition to using primary and secondary sources, this paper uses a mixed-methods research design. I rely on my deep personal knowledge of Tunisia to report typical wasta 
scenarios. My fluency in Tunisian Derja ${ }^{11}$ is also helpful in surveying popular expressions that people use to refer to wasta. Using this selection of linguistic data, I make a sociolinguistic argument on the linguistic encoding of wasta and what the latter reveals about Tunisian everyday politics and the negotiation of power. In the last chapter, I suggest a research agenda that centers ethnographic data. This will be mainly based on literature on political ethnography.

Because of lack of funding, in-person interviews were not possible. Several attempts to do phone interviews have failed because of time difference and general mistrust. This is unsurprising, considering the contested nature of wasta. Instead, I chose to have this fruitless experience inform my research agenda to argue for better ways that wasta can be studied.

\footnotetext{
${ }^{11}$ Derja refers to the colloquial language spoken in Tunisia. Its language status is still debated, with most people referring to as a dialect of Arabic. In this paper, I refer to it as a language because it violates the principle of mutual intelligibility when compared to Levantine dialects.
} 


\section{Part Two}

In this chapter, I demonstrate that the widespread use of wasta in Tunisia as we know it is a result of the legacies of colonialism and post-colonial governments' authoritarian policies that undermined kin-based structures in order to implement a modernist project.

\section{The Colonial and the Postcolonial}

In "Notes on the (Post)Colonial in the Maghreb" (2009), Hannoum argues that "colonialism has introduced and imposed its own webs of significance into the colonies and [shows] the conditions under which the colonized became caught in webs of significance that they themselves had not spun" (324). Hannoum presents what he calls "a preliminary investigation on how the colonial continues in the contemporary Maghreb” (325). He engages an anthropological critique of the discourse of both colonialism and nationalism. Through examples from the colonial historiography of the Maghreb, i.e. colonial knowledge as power wielding, the national elite, literary and cultural productions, and finally postcolonial historiography, Hannoum deconstructs nationalist claims of regeneration after independence. Instead, he argues that a more fitting dichotomy is that of the pre-colonial versus the (post)colonial.

Before the French colonized the Maghreb, they engaged in an enormous process of knowledge restructuring. Hannoum argues that before the introduction of the Arab Bureau (Hannoum 2008), a French colonial body which produced ethnographic and historiographic literature on the Maghreb in general but Algeria in particular, historical texts distinguished the Maghreb by a striking racial diversity: "Jews, Turks, Moors, Coloughli [descendants of Turkish fathers and Moorish mothers], Berbers, and Arabs” (326). French historiographic 
literature produced texts that reduced the racial makeup of North Africa to a dichotomy of Berber versus Arab. Berbers physically resembled white Europeans, and as such they were depicted as primitive ancestors to the modern French come to the rescue-to unification. The colonial discourse "concentrated around the nation and used the opposition Arab versus Berber to demonstrate the impossibility of nationhood in the Maghreb” (328). Both Berbers and Arabs, nomadic by tradition, "cannot conceive of existence beyond the tribe" and so tribalism became a symbol for their primitiveness and backwardness. Nationhood, then, was the mark of modernity, civility, and national progress (Hannoum 2009).

These categories apply to the introduction of bureaucratic processes into the colonies which created a conflict in the "native" traditions. Traditionally, tribes were the dominant social categories, and tribe elders would play the role of 'wasta' in mediating conflict within their tribe or in relation to other tribes. Social interactions are, thus, extremely personal and a person's biggest capital is their social standing. Antoun (2000) argues that tribal structures serve the purpose of forming trust and "accomplishing social goals" (444). Explaining the variation in family law conservatism in Tunisia, Algeria, and Morocco, Charrad (2001) writes that Bourguiba ${ }^{12}$ sidelined tribe leaders upon independence from the French in 1956. He believed that their primitive structures and beliefs would hold back his project of a modern, progressive Tunisia. Admittedly, he was a centrist whose politics angered the more revolutionary tribal groups whose identity was antithetical to the colonial project (Christian, white, Francophone, rational, etc.).

Accessing services, like employment, obtaining and renewing identification documents, and securing positions in training programs and such became standard

\footnotetext{
12 Tunisia's first president.
} 
procedures. In theory, these services are impersonal and non-discriminating, yet approval is often acquired, or in most cases, expedited through wasta that is often family-based. The result of this structure is entrenched inequalities because of the margin that wasta allows for the abuse of social capital.

\section{The Evolution of Wasta}

Speaking in the context of the MENA region, Barnett et al. (2013) distinguish between what they call "old wasta" and "new wasta":

With old wasta, the tribal leader sought to gain an advantage on behalf of the tribal group so that wasta worked from top down. New wasta, while still yielding advantage for the tribal group, works from bottom up. Moreover, with old wasta tribal elders and leaders gained status and authority via their role as middlemen. This source of status and authority is largely lost with new wasta. (43)

This distinction is important to understand how wasta changed with the evolution of tribes. In Tunisia today, it is easy to determine a person's tribal belonging as well as where their ancestors originally came from just by knowing their last name. As such, it is common to refuse service to a person if the employee has personal prejudice against a person of a certain tribal ancestry. The employee might oblige begrudgingly, but the person seeking the service would most probably be dealing with the "dark" side of wasta—endless referrals, and the famous Tunisian response "come back tomorrow"13 or "the person in charge is out of office and will be back this afternoon" ${ }^{\prime 14}$.

\footnotetext{
أرجع غدوة 13

${ }^{14}$ All parties involved know that it's a decoy, and there is no point in coming back in the afternoon.
} 


\section{Is Wasta a Form of Corruption?}

Transparency International defines corruption as "the abuse of entrusted power for private gain. Corruption can be classified as grand, petty and political, depending on the amounts of money lost and the sector where it occurs." It also defines petty corruption as:

Everyday abuse of entrusted power by public officials in their interactions with ordinary citizens, who often are trying to access basic goods or services in places like hospitals, schools, police departments and other agencies.

Based on this definition, it can be understood that this involves wasta as well. After all, it does involve abusing entrusted power and controlling access to basic goods and services. However, in this section I argue that wasta is different from corruption.

Examining Tunisian Derja, I find that expressions that refer to wasta are often used in a way that does not differentiate between corruption and wasta. At a surface level, this could mean that Tunisians are so desensitized to corruption that their linguistic encoding of their worldview normalizes petty corruption. However, this section draws from Sociolinguistics and Pragmatics to argue that the casual everyday references to wasta give insight into how people think of power and access to resources.

\section{Linguistic Encoding of Wasta}

In Table 1, I present as selection of Tunisian expressions that are used every day in response to prompts that have to do with accessing jobs and services, followed by an analytical commentary on this data. 
Table 1. Expressions in Tunisian Derja

\begin{tabular}{|c|c|c|}
\hline & Original & Translation \\
\hline 1. & بعثي (فلان) & (X) sent me \\
\hline 2. & كلمك عليا (فلان) & (X) contacted you about me \\
\hline 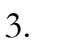 & جينك على هاك القضية & I'm here for the (merchandise/service) \\
\hline 4. & بن عميست & $\begin{array}{c}\text { A mix of French and Arabic: Ben- } \\
\text { Ammiste, a person who uses family } \\
\text { connections. Could also be used to } \\
\text { describe those who use wasta (either client } \\
\text { or patron) }\end{array}$ \\
\hline 5. & من غادي لغادي؟ & $\begin{array}{l}\text { Literally "from there to there?". Used in } \\
\text { response to lack of respect to hierarchy, } \\
\text { status, etc. }\end{array}$ \\
\hline 6. & (فلان) عندو الاكتاف & (X) has some robust wasta \\
\hline 7. & النسيب & Son-in-law \\
\hline 8. & Une personne serviable & $\begin{array}{l}\text { A hospitable person (reference to how } \\
\text { well they respond to wasta) }\end{array}$ \\
\hline 9. & تفضل، مرحبا بيك في كل وقت & You're welcome any time \\
\hline 1( & 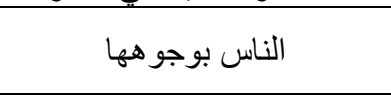 & $\begin{array}{l}\text { I can tell from your/their face (e.g. this } \\
\text { person looks/seems trustworthy) }\end{array}$ \\
\hline 11 & القفة & $\begin{array}{c}\text { Literally 'goodie bag' / colloquially: } \\
\text { sycophancy }\end{array}$ \\
\hline
\end{tabular}

This selection of common expressions used on a daily basis in Tunisia speaks volumes about how public servants, namely employees in state administrations (like the postal office, the municipality, police station, etc.), "perform" wasta.

In The Presentation of Self in Everyday Life, Goffman (1959) develops his 'dramaturgical model'. This model is based on Melancholy Jacques's soliloquy in As You Like It. In the famous opening lines, Jacques declares "All the world's a stage / And all the men and women merely players". Goffman argues, thus, that our public selves are continually adapted to fit the image that we want to project about ourselves and to fit the social setting of the interaction. The American Psychological Association defines situated identity theory as "the theory that individuals take on different roles in different social and cultural settings, so that a person's behavior pattern may shift radically according to the situation and the others with whom he or she is interacting" (APA). Goffman's concept of the performative self, which 
builds on situated identity theory, can be applied in this case to understand the performance of wasta, specifically how employees in public administration play both the role of a client or a wasta, depending on who they're speaking to.

Based on the preceding selection of expressions commonly used to refer to wasta, I identify three central elements of wasta: announcement, respect for hierarchy, and reputation.

Announcement of Wasta

Wasta has its internal rules. Announcing it is of utmost importance. The first three expressions are the most common ones used to announce wasta, usually declaring the name of the wasta, or the mediator, that established this connection. Prior knowledge on the part of the employee is not always necessary. In fact, it depends on how close the mediator is to the employee. If their relationship is robust, they would trust that whoever announces the name of the mediator were indeed 'sent' by said mediator. However, if a wasta is not direct, or was established through another wasta, prior knowledge would be needed. This unspoken rule is established to protect against false wasta: citizen A could lie about their wasta in the hopes of having their service fulfilled.

Hierarchy

Respect for hierarchy is an essential element of wasta. This is due, not simply to real hierarchy within administrations, but to lower-ranked employees overstepping the limits of their influence to serve or refuse service. Expression number 7 is a classic example of a 
wasta-type interaction where a citizen could offend a doorman ${ }^{15}$ by simply greeting them without sharing the purpose of their visit or who they are. In this case, the doorman's situated identity projects a higher status than he actually has.

If a citizen uses wasta to approach employee $A$, but the latter is out of office ${ }^{16}$, the service would be delegated to the person higher up (employee B) in terms of hierarchy. Rarely would it be a person of equal or lower status. Fulfilling the request also depends on the impression that employee B has of employee A's, or whether or not there is preexistent conflict. Therefore, this can be the citizen's lucky day because they could be accidentally referred to someone with bigger prerogatives, or they can have wasta backfire. Little attention is usually given to how urgent is the citizen's need for the service is or to the principle of impartiality upon which bureaucracies are built.

Figure 2 below represents the possible scenarios that could take place when wasta is in action.

\section{Reputation}

Wasta is highly personalistic and it is similar to the general understanding of clientelism as a contingent/reciprocal process. As Hicken notes, "the delivery of a good or service on the part of both the patron and client is in direct response to a delivery of a reciprocal benefit by the other party, or the credible promise of such a benefit" (291). In the case of wasta, more weight is given to the 'promise' of reciprocity. As such, a person's reputation depends on how well they peddle connections and serve citizens who arrive to

\footnotetext{
${ }^{15}$ Men almost always are employed as doormen.

${ }^{16}$ As is often the case with administration employees, who are often "away on business" when in fact they could be on a cigarette break.
} 
his/her office through wasta. Expressions 6, 8, 10, apply to this element of wasta.

Expression 6, "(X) has robust wasta" reveals that people take pride in being well-connected. This in turn, contributes to the strength of their own 'promise of reciprocity' in the eyes of a patron. Expression 8 is indeed a major compliment any administration official can receive. It does not refer to hospitality in the typical sense of the word. Describing someone as 'serviable', means they are likely to prioritize those who are backed up by wasta, at the expense of those who approach him/her with a meager form or application dossier in hand. Lastly, describing someone as 'Ben-Ammiste' carries the understanding that they are most probably receiving bribes for the service, not only responding to wasta for the sake of social capital.

Figure 2. Common wasta scenario

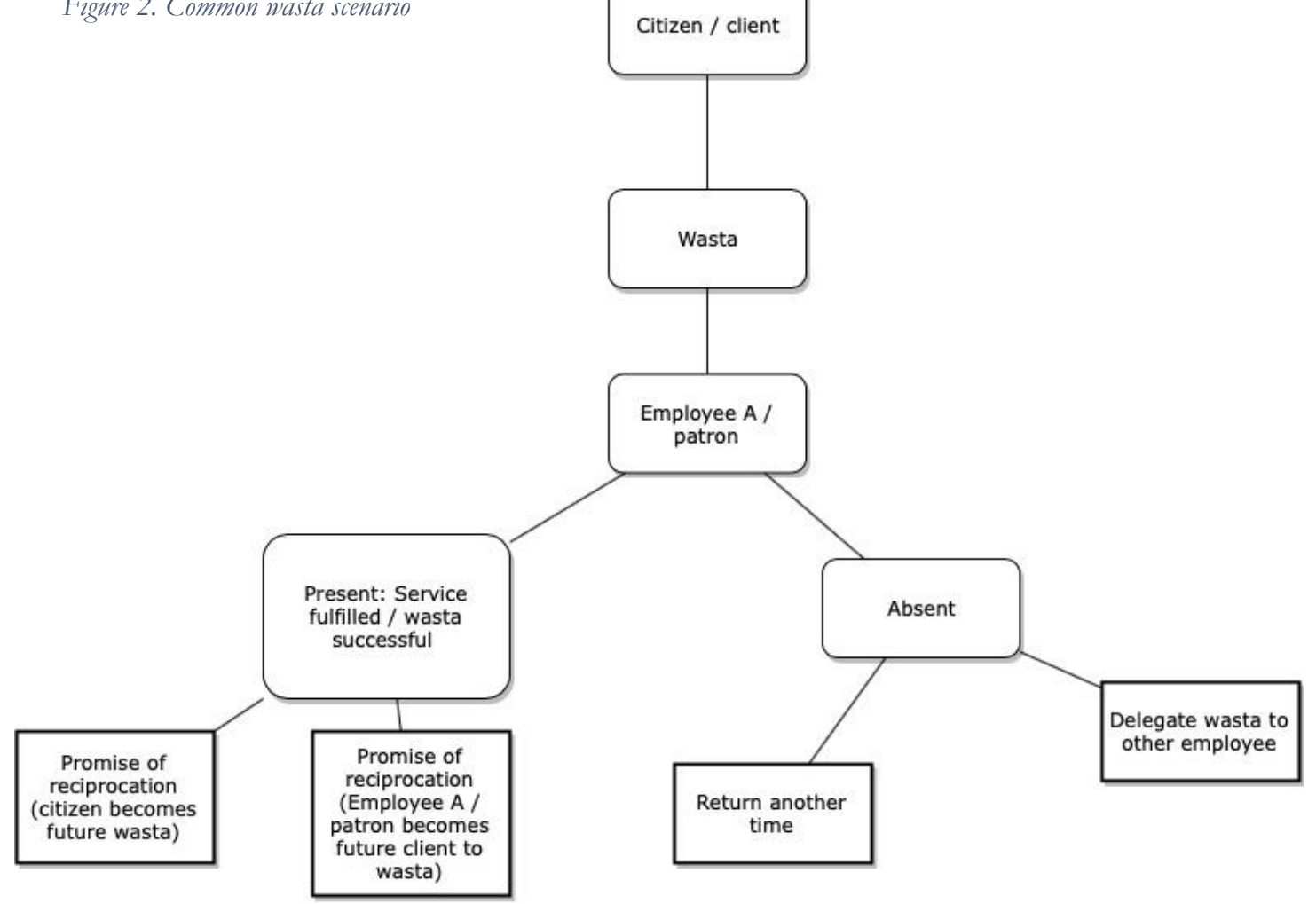


Party Politics and Wasta

The Political Economy of Wasta

In her seminal book, The Force of Obedience: The Political Economy of Repression in Tunisia, Béatrice Hibou (2011) writes one of the most compelling works on the role of the banking sector in reproducing authoritarian structures. After 9 years of fieldwork, she writes about how interconnected all sectors are: banking, political discourse, and international organizations' complicity in Ben Ali's police state.

She argues that contending with the explanation of the oppressive relationship between the people and Ben Ali as a vertical one based on the use of violence and coercion tells only part of the story. "No government is exclusively based on violence and repression," she writes (11). Her aim is "to understand, over and beyond the most brutal repression, the modes of government and the concrete economic apparatuses of power that render constraint painless and even invisible" (9).

In other words, the book shows how the regime is set up in a way that cultivates in people a 'desire' for integration into this system. This integration guarantees them social mobility and economic opportunities as they participate in the weaving of the "fiction" of modernization and economic security. Wasta, in this context, is one of the features of Ben Ali's world that carries over from before 2011 to this day. Trying to decipher the workings of everyday wasta falls under a tradition of politics "from below". It is an example of Foucauldian power relations: ambivalent, negotiated, and constantly contested.

Because wasta remains a striking feature of Tunisian society, democratization could potentially exacerbate it. Before 2011, all wasta goes through the RCD and its members. 
Administration officials' "situated identities" are of RCD-istes first, and citizens second. This created a thick barrier between political dissent and access to basic services. If the RCD learned that a citizen disapproves of any state policy, then the wasta 'machinery' automatically shuts its doors. Any "mediator" would be endangering their livelihood and their family's if they helped someone with a political reputation.

Hibou's insights into the banking system show how it revolves around bad debt and normalizes it, and how every participant from politicians to businessmen to average citizens depend on it-in her words, "power by credit, life on credit" (183). The banking sector is deeply social: businesses get loans only if they have enough social capital, not according to objective economic metrics of risk assessment. In other words, the success of any business depends on how well they behave within the ruling party. Abstention is seen as dissent and so is punished the same way-exclusion.

\section{Change and Continuity}

Hibou's study is even more striking when the banking system is examined, now, 8 years after the fall of the RCD; no reforms have been put into place to change how loans are allocated. Therefore, it is safe to conclude that the same mechanisms that she describes in the first quarter of this decade remain mostly unchanged. As she recounts, Ben Ali's rule was associated with the Tunisian 'economic miracle', a myth he reinforced by constantly showcasing ad nauseam, both to the country and the world, several fabricated figures as evidence of economic prosperity. This 'Tunisian miracle' was consolidated through an official discourse of exceptionalism, modernity, and security ${ }^{17}$.

\footnotetext{
${ }^{17}$ For more details, see Amnesty International's June 2009 report entitled “Tunisia: Behind Tunisia's 'Economic Miracle': Inequality and Criminalization of Protest"'
} 
I argue that the survival of this myth of economic prosperity can be explained by the gap it fills: it responds to people's aspirations and gives meaning to an everyday life of control and surveillance. And it rests on what Hibou calls a 'security pact' (181). She stresses that this 'pact' should not be understood as an exchange, it is rather The assurance of order and tranquility... the Tunisian authorities thus make it a point of honor to enumerate the benefits that they are bestowing on their middle classes, and it is no coincidence that speeches focus on precisely this dimension: growth annually rises to around five percent, fostering a real development in the country; nearly 80 percent of families own their own accommodation; cars are made more popular both by programs that provide purchasing aid and, in periods when petrol prices go up, by oil subsidies; electrification and water conveyance affect over 90 percent of the population; telephones are increasingly accessible, as is the internet; birth rates have fallen and demographic growth has been limited thanks to an active family planning policy; etc. the Plan is the main indicator of the pact's effectiveness: as a technique of assessment, it attempts to order everything so that the objective of security can be attained" (183).

Hibou's book presents a rare analysis of Ben Ali's rule in particular, and domination in general. It remains perhaps one of the best works on Tunisia, and not many interrogate power the way that her work does. It shows how every aspect of everyday life revolves around the ruling party. It is difficult, almost impossible, to do anything without being under the watchful eye of the party, whether real or perceived.

What Hibou's argument shows is that power can be reified, not through weapons, but through controlling the public and what they perceive as 'normal'. How much can a "democratic transition" achieve in the absence of progressive structural reforms that could 
perhaps make wasta obsolete? Without structural reforms (not simply legal amendments), the state continues to hamper citizen's prosperity and perpetuate dependence on its wasta.

Wasta After 2011

The previous section attempted to go beyond the simple understanding of wasta as corruption and show how, even when following legal procedures, it can still be a way that the state imposes obedience. It also showed how at the lowest level of everyday interaction, power is reified through the need that it creates: in the case of wasta, it creates dependence on state officials, personalistic ties, and arbitrary fulfillment of basic services. This section asks: how much has changed since the fall of the ruling party? I argue that democratization caused a reshuffling of social capital and the end of the RCD's monopoly over wasta, yet it has not addressed the root causes of wasta.

I explain the persistence of wasta using French theorist Pierre Bourdieu's concept of habitus. It is "a way of describing the embodiment of social structures and history in individuals. It is a set of dispositions, internal to the individual, that both reflects external social structures and shapes how the individual perceives the world and acts in it." (Power 1999, 48-49; emphasis added). The interaction between the social context and the individual's internalization of it can make it exceedingly difficult to simply "shake off” 23 years of autocratic rule and what it entails like fear, conditioned social relations, policed discourse, censored thoughts, threat of violence, and selective propaganda.

In other words, complicated bureaucratic procedures combine with highly personalistic means to acquire services and create the most pervasive means of non-violent oppression: the administration. What makes it so pervasive is the fact that it creates demand. 
Tunisians are so accustomed to using wasta that despite its drawbacks, it remains highly sought after. 


\section{Part Three}

\section{Research Agenda}

Perhaps the lack of attention to wasta is due to the research methods commonly used in the Middle East and North Africa. In this section, I develop a research agenda that rethinks how we study wasta in a way that respects its internal logic.

\section{Surveys and Public Opinion}

The Arab Barometer is the most robust cross-national survey of the Middle East and North Africa currently in use. Its four waves have been heavily cited in Political Science research on the region to understand changes in public opinion over time. One of its strengths is the repetition of questions from one wave to another in order to observe trends. Unfortunately, this does not apply to wasta. In fact, the Arab Barometer rarely refers to wasta; and when it does, it is to ask whether or not and how often respondents used it. In fact, only two waves ever use the word 'wasta' or connections. However, all waves refer to corruption, bribery, and the government's role in curbing both.

Wave I was conducted between 2006 and 2007 in Algeria, Bahrain, Jordan, Lebanon, Morocco, Palestine, and Yemen. Only three questions mention wasta: 
Figure 3 Questions from 226 and 227 from $W$ ave $I$

\begin{tabular}{|c|c|c|c|}
\hline 226 & $\begin{array}{l}\text { During the past five years, have you ever used } \\
\text { wasta to achieve something personal, family } \\
\text { related, or a neighborhood problem? }\end{array}$ & $\begin{array}{l}\text { 1. Yes } \\
\text { 2. No __ move to } 228 \\
\text { 8. [Do not read] Can't choose [move to 228] } \\
\text { 9. [Do not read] Decline to answer [move to 228] }\end{array}$ & $\frac{1}{1}$ \\
\hline 227 & $\begin{array}{l}\text { Please list the type of wasta: } \\
\text { [Note to researcher: there may be more than } \\
\text { one answer] }\end{array}$ & $\begin{array}{l}\text { 1. Government officials } \\
\text { 2. Members of parliament or } \\
\text { 3. Governorate officials or community leaders } \\
\text { 4. Traditional leaders (head of tribe, etc) } \\
\text { 5. Religious official, such as imam } \\
\text { 6. Civil society organizations } \\
\text { 8. [Do not read] Can't choose } \\
\text { 9. [Do not read] Decline to answer }\end{array}$ & $\begin{array}{l} \\
\\
\end{array}$ \\
\hline
\end{tabular}

Figure 4 Question 506 from Wave I

\begin{tabular}{|c|c|c|c|c|c|c|c|}
\hline 506 & $\begin{array}{l}\text { What is the importance of a person's professional } \\
\text { other factors? Please indicate whether each is more } \\
\text { experience and professional qualifications. }\end{array}$ & alification & $\begin{array}{l}\text { in obtaini } \\
\text { qually im }\end{array}$ & $\begin{array}{l}\text { g a gover } \\
\text { ortant, or }\end{array}$ & $\begin{array}{l}\text { nent job } \\
\text { s impor }\end{array}$ & $\begin{array}{l}\text { Jordan re } \\
t \text { as a pers }\end{array}$ & \\
\hline & Factors & $\begin{array}{l}\text { More } \\
\text { importa } \\
\text { nt than } \\
\text { experie } \\
\text { nce and } \\
\text { qualific } \\
\text { ations }\end{array}$ & $\begin{array}{c}\text { Equal } \\
\text { importa } \\
\text { nce } \\
\text { with } \\
\text { experie } \\
\text { nce and } \\
\text { qualific } \\
\text { ations }\end{array}$ & $\begin{array}{c}\text { Less } \\
\text { importa } \\
\text { nt than } \\
\text { experie } \\
\text { nce and } \\
\text { qualific } \\
\text { ations }\end{array}$ & $\begin{array}{l}\text { [do not } \\
\text { read] } \\
\text { Can't } \\
\text { choose }\end{array}$ & $\begin{array}{l}\text { [do not } \\
\text { read] } \\
\text { Decline } \\
\text { an } \\
\text { answer }\end{array}$ & \\
\hline 1. A & son's political affiliations & 1 & 2 & 3 & 8 & 9 & $L_{1}$ \\
\hline 2. A & son's family or tribal affiliation & 1 & 2 & 3 & 8 & 9 & 1 \\
\hline 3. $\mathrm{Tl}$ & quality of a person's personal connections or wasta & 1 & 2 & 3 & 8 & 9 & 1 \\
\hline
\end{tabular}

Waves II (2010-11; Algeria, Egypt, Iraq, Jordan, Lebanon, Morocco, Palestine, Saudi Arabia, Sudan, Tunisia, Yemen) and III (2012-14; Algeria, Egypt, Iraq, Jordan, Kuwait, Lebanon, Libya, Morocco, Palestine, Sudan, Tunisia, Yemen) make no mention of wasta whatsoever. Finally, Wave IV (2016-17; Algeria, Egypt, Jordan, Lebanon, Morocco, Palestine, Tunisia) asks only one question about wasta: 
Figure 5 Question q213 from Wave IV

\begin{tabular}{|c|c|c|}
\hline q213 & $\begin{array}{l}\text { Some people say that nowadays it is impossible to } \\
\text { get a job without connections (wasta) while others } \\
\text { say that jobs are only available to qualified } \\
\text { candidates. Based on a recent experience (or } \\
\text { experiences) you are personally aware of, do you } \\
\text { think that...? (Read): }\end{array}$ & $\begin{array}{l}\text { 1.Obtaining employment through } \\
\text { connections is extremely widespread } \\
\text { 2. Employment is sometimes obtained } \\
\text { through connections } \\
\text { 3. Employment is mostly obtained } \\
\text { without connections } \\
\text { 4. I do not know of any relevant } \\
\text { experiences. } \\
\text { 5. I do not know examples concerned } \\
\text { 98. I don't know (Do not read) } \\
\text { 99. Declined to answer (Do not read) }\end{array}$ \\
\hline
\end{tabular}

While I do recognize that these surveys applications can be limited in that they ask 'what' but not 'how' or 'why', I suggest that they have the potential to reveal more insight about people's attitudes towards wasta and their perspectives depending on where they stand: have wasta, don't have wasta, client, patron, middleperson, administration official, citizen, man, woman, senior citizen/retiree, etc. Incorporating targeted questions about the identity of respondents could frame their perspective and give us a better view of how wasta is perceived depending on how much wasta a person has access to.

Second, surveys can be developed as well as conducted in local dialects, bridging the gap between what researchers think they are signaling and what respondents are actually hearing. As mentioned earlier, a person's attitude towards wasta can depend on where they stand, or whether they actively benefit from it. When the Arab Barometer asks about corruption or bribes, respondents can understand it as 'wasta' or the other way around. Making questions more specific could avoid misunderstandings and so, unreliable data.

For example, interviewers could ask if interviewees think that forms and applications are reliable ways to get services, what means they use to acquire wasta, if wasta is direct or 
indirect (i.e. do they know their wasta directly or is it acquired through a reference), and in countries like Algeria and Morocco references to the army and the monarchy, respectively, can also be helpful in showing variation in the type of wasta, etc. Surveys can use more local terms to refer to wasta. While the word wasta is very common in the Middle East, North Africans can be more responsive to other terms such as 'piston', 'aktaf'", or 'maarifa'.

In other words, I find that a phenomenon this widespread in the region should enjoy more probing questions, especially ones that center the respondent's world view and their dialect.

Wasta and Political Ethnography

Perhaps the reason that surveys can only go so far in unpacking the politics of wasta is because of its political nature: admitting one uses wasta depends on which side of wasta they stand, the privileged or the dispossessed. Asking someone directly about wasta can cause 'negative face' (Goffman 1959) meaning that the survey respondent or the interviewee can feel embarrassed or questioned. In an authoritarian regime, they can get quite suspicious and fear persecution. In this section, I argue that because of the controversial nature of wasta, a better strategy would be to not interrogate directly and impersonally, but rather observe wasta as it unfolds.

In Political Ethnography: What Immersion Contributes to the Study of Power (2009), Edward Schatz writes in the introduction that ethnography can be understood in two ways. First, as participant observation, it can mean "immersion in a community, a cohort, a locale, or a

\footnotetext{
18 Aktaf is often used in Tunisia. Its literal translation is 'shoulders', a metaphor that uses shoulders as a symbol for reliability.

${ }^{19}$ Marifa (or maarif as well in Tunsiia) is commonly used across the Maghreb. It means 'knowledge', but is used to refer to connections.
} 
cluster of related subject positions" (5). Second, ethnography can also refer to a "sensibility that goes beyond face-to-face contact ... and [is] an approach that cares-with the possible emotional engagement that implies — to glean the meanings that the people under study attribute to their social and political reality" (5). In other words, studying wasta with an ethnographic lens has the potential to go beyond the first step of establishing the existence of wasta, its scope, and purposes. In fact, ethnography can unveil the meaning that clients ascribe to their position in social networks, to their motivation behind pursuing any means possible to exist within the "web of significance" (Hannoum 2009) that authoritarian regimes weave.

\section{Conclusion}

This paper sought to achieve three things. First, I surveyed the literature on clientelism and wasta and found a surprising lack of interest in wasta. Second, I tried to parse out the concept of wasta in its application to the Tunisian administration and bureaucratic structures to argue that the state's interests (whether before or after 2011 and the fall of the ruling party) lie in creating dependence on personalistic ties to enforce discipline and state obedience. Finally, I develop a modest research agenda and suggest ways that Political Scientists can improve their research design to better suit the internal logic of wasta.

The limitations of this paper lie in the lack of robust literature that it could have responded to. In this case, ethnographic data becomes even more important as first-person experiences are needed to open the way for more research into this valuable phenomenon. Research can then begin to dig deeper into gender dynamics in wasta. "Old wasta" was typically exercised by the patriarch of the tribe or family. We can investigate if this still holds 
nowadays and whether or not women operate differently from men. What can this tell us about women's negotiation of power and citizenship. In other words, "politics from below" is key to understanding the future of Tunisian politics. 


\section{Bibliography}

Abdel-Samad, Mounah, and Lindsay J. Benstead. 2016. "Why Does Electing Women and Islamist Parties Reduce the Gender Gap in Service Provision?” In . Vol. 5.

Al-Ramahi, Aseel. 2008. "Wasta in Jordan: A Distinct Feature of (And Benefit for) Middle Eastern Society.” Arab Law Quarterly 22 (1): 35-62.

American Psychological Association. n.d. "Situated Identity Theory." In APA Disctionary of Psychology. Accessed Jan 20, 2019. https://dictionary.apa.org/situated-identity-theory.

Amin Mohamed, Ahmed, and Hadia Hamdy. 2008. "The Stigma of Wasta: The Effect of Wasta on Perceived Competence and Morality.” Working Papers 5. The German University in Cairo, Faculty of Management Technology. https://EconPapers.repec.org/RePEc:guc:wpaper:5.

Anderson, Lisa. 2014. The State and Social Transformation in Tunisia and Libya, 1830-1980. Princeton University Press.

Anderson, Robert. 2016. "Wasta Seen as Main Source of Corruption in Saudi." Gulf Business, June 21, 2016. https://gulfbusiness.com/wasta-seen-main-cause-corruption-saudi/.

Antoun, Richard T. 2000. "Civil Society, Tribal Process, and Change in Jordan: An Anthropological View.” International Journal of Middle East Studies 32 (4): 441-63. https://doi.org/10.1017/S0020743800021164.

Auyero, Javier. 1999. "“From the Client's Point(s) of View”": How Poor People Perceive and Evaluate Political Clientelism."” Theory and Society 28 (2): 297-334.

—. 2000. "The Logic of Clientelism in Argentina: An Ethnographic Account." Latin American Research Review 35 (3): 55-81. 
2001. Poor People's Politics: Peronist Survival Networks and the Legacy of Evita. Durham:

Duke University Press Books.

Barnett, Andy, Bruce Yandle, and George Naufal. 2013. "Regulation, Trust, and Cronyism in Middle Eastern Societies: The Simple Economics of 'Wasta."' The Journal of SocioEconomics 44 (June): 41-46. https://doi.org/10.1016/j.socec.2013.02.004.

Benstead, Lindsay J. 2016. “Why Quotas Are Needed to Improve Women’s Access to Services in Clientelistic Regimes.” Governance 29 (2): 185-205. https://doi.org/10.1111/gove.12162.

—. 2017. "Survey Research in the Arab World." In Oxford University Press Handbook on Polling and Polling Methods, edited by Lonna Rae Atkeson and R. Michael Alvarez. Vol. 1. Oxford University Press. https://doi.org/10.1093/oxfordhb/9780190213299.013.14.

Berger, Ron, Avi Silbiger, Ram Herstein, and Bradley R. Barnes. 2015. “Analyzing Businessto-Business Relationships in an Arab Context.” Journal of World Business 50 (3): 454 64. https://doi.org/10.1016/j.jwb.2014.08.004.

Blaydes, Lisa. 2008. “Authoritarian Elections and Elite Management: Theory and Evidence from Egypt.”. Princeton University.

Charrad, Mounira. 2001. States and Women's Rights: The Making of Postcolonial Tunisia, Algeria, and Morocco. University of California Press.

Chebaane, Emna. 2019. “Tunisia: Where Running from Police Can Be Deadly.” Amnesty International.

Danet, Brenda. 1989. Pulling Strings: Biculturalism in Israeli Bureaucracy. SUNY Press. 
Doughan, Yazan. 2017. "Corruption in the Middle East and the Limits of Conventional Approaches."

Gans-Morse, Jordan, Sebastián Mazzuca, and Simeon Nichter. 2014. 'Varieties of Clientelism: Machine Politics during Elections." American Journal of Political Science 58 (2): 415-32. https://doi.org/10.1111/ajps.12058.

Goffman, Erving. 1959. The Presentation of Self in Everyday Life. 1 edition. New York, NY: Anchor.

Gouldner, Alvin W. 1960. “The Norm of Reciprocity: A Preliminary Statement.” American Sociological Review 25 (2): 161-78. https://doi.org/10.2307/2092623.

Grillmeier, Franziska. 2018. 'Prominent Tunisian Cartoonist Says She Hopes There's Another Uprising.” Roads \& Kingdoms. April 3, 2018. https://roadsandkingdoms.com/2018/nadia-khiari-willis-from-tunis/.

Hachemaoui, Mohammed. 2013. Clientélisme et patronage dans l'Algérie contemporaine. Paris: Karthala.

Hannoum, Abdelmajid. 2008. "The Historiographic State: How Algeria Once Became French." History and Anthropology 19 (2): 91-114. https://doi.org/10.1080/02757200802320876.

- 2009. "Notes on the (Post)Colonial in the Maghreb." Critique of Anthropology 29 (3): 324-44. https://doi.org/10.1177/0308275X09336702.

Hibou, Beatrice. 2011. The Force of Obedience: The Political Economy of Repression in Tunisia. Translated by Andrew Brown. Cambridge: Polity.

Hicken, Allen. 2011. "Clientelism.” Annual Review of Political Science 14 (1): 289-310. https://doi.org/10.1146/annurev.polisci.031908.220508. 
Kimball, Sam. 2019. “Tunisia’s Authoritarians Learn to Love Liberalism.” Foreign Policy, June 14, 2019. https:// foreignpolicy.com/2019/06/14/tunisias-authoritarians-learn-tolove-liberalism/.

Kitschelt, Herbert, and Steven I. Wilkinson. 2007. Patrons, Clients and Policies: Patterns of Democratic Accountability and Political Competition. Cambridge University Press.

Lackner, Helen. 2016. “Wasta: Is It Such a Bad Thing? An Anthropological Perspective.” In The Political Economy of Wasta: Use and Abuse of Social Capital Networking, edited by Mohamed A. Ramady, 33-46. Cham: Springer International Publishing. https://doi.org/10.1007/978-3-319-22201-1_3.

Ledeneva, Alena C., and Alena V. Ledeneva. 1998. Russia's Economy of Favours: Blat, Networking and Informal Exchange. Cambridge University Press.

Liddell, James. 2010. "Notables, Clientelism and the Politics of Change in Morocco." The Journal of North African Studies 15 (3): 315-31. https://doi.org/10.1080/13629380903175438.

Loewe, Markus, Jonas Blume, Verena Schönleber, Stella Seibert, Johanna Speer, and Christian Voss. 2007. “The Impact of Favouritism on the Business Climate: A Study on Wasta in Jordan.” SSRN Scholarly Paper ID 2218821. Rochester, NY: Social Science Research Network. https://papers.ssrn.com/abstract=2218821.

Lust, Ellen. 2009. "Competitive Clientelism in the Middle East.” Journal of Democracy 20 (3): 122-35. https://doi.org/10.1353/jod.0.0099.

Nuijten, Monique, and Gerhard Anders. 2007. Corruption and the Secret of Law: A Legal Anthropological Perspective. Ashgate Publishing, Ltd. 
Pellicer, Miquel, Eva Wegner, Markus Bayer, and Christian Tischmeier. 2018. "Clientelism from the Client's Perspective: A Framework Based on a Systematic Review of Ethnographic Literature," April, 30.

Pellicer, Miquel, Eva Wegner, Lindsay Benstead, and Ellen Lust. 2017. “Poor People’s Beliefs and the Dynamics of Clientelism," September, 44.

Piattoni, Simona. 2001. Clientelism, Interests, and Democratic Representation: The European Experience in Historical and Comparative Perspective. Cambridge University Press.

Power, Elaine M. 1999. “An Introduction to Pierre Bourdieu’s Key Theoretical Concepts.” Journal for the Study of Food and Society 3 (1): 48-52. https://doi.org/10.2752/152897999786690753.

"Pragmatics". In Encyclopedia Britannica. Accessed Feb 25, 2019. https://www.britannica.com/science/pragmatics.

Ramady, Mohamed A., ed. 2016. The Political Economy of Wasta: Use and Abuse of Social Capital Networking. Cham: Springer International Publishing. https://doi.org/10.1007/9783-319-22201-1.

Richter, Thomas. 2007. The Political Economy of Regime Maintenance in Egypt: Linking External Resources and Domestic Legitimation. https:/ / www.gigahamburg.de/en/publication/the-political-economy-of-regime-maintenance-in-egyptlinking-external-resources-and.

Smith, Peter B., Hai Juan Huang, Charles Harb, and Claudio Torres. 2012. "How Distinctive Are Indigenous Ways of Achieving Influence? A Comparative Study of Guanxi, Wasta, Jeitinho, and 'Pulling Strings.’” Journal of Cross-Cultural Psychology 43 (1): 13550. https://doi.org/10.1177/0022022110381430. 
Stokes, Susan C. 2011. "Political Clientelism." In The Oxford Handbook of Political Science, edited by Robert E. Goodin. Oxford University Press. https://doi.org/10.1093/oxfordhb/9780199604456.013.0031.

Transparency International. “Transparency International - What Is Corruption?” Accessed May 3, 2019. https://www.transparency.org/what-is-corruption\#define.

“Tunisia: Behind Tunisia’s 'Economic Miracle': Inequality and Criminalization of Protest | Amnesty International.” 2009. Amnesty International. https://www.amnesty.org/en/documents/mde30/003/2009/en/.

UNDP. 2014. "Tunisia Launches Truth and Dignity Commission." https://www.undp.org/content/undp/en/home/presscenter/articles/2014/06/09/ tunisia-launches-truth-and-dignity-commission.html.

Velez-Calle, Andres, Cristina Robledo-Ardila, and Juan David Rodriguez-Rios. 2015. “On the Influence of Interpersonal Relations on Business Practices in Latin America: A Comparison with the Chinese Guanxi and the Arab Wasta." Thunderbird International Business Review 57 (4): 281-93. https://doi.org/10.1002/tie.21669.

Wegner, Eva, and Francesco Cavatorta. 2018. "Revisiting the Islamist-Secular Divide: Parties and Voters in the Arab World." International Political Science Review, August, 019251211878422. https://doi.org/10.1177/0192512118784225.

Wehr, Hans. 1993. Arabic-English Dictionary: The Hans Wehr Dictionary of Modern Written Arabic. Edited by J. Milton Cowan. 4th edition. Urbana, IL: Spoken Language Services. willis from tunis. 2018. "Publié dans @sinemensuel \#tunisiepic.twitter.com/jPJBQezMLI." Tweet. @willisfromtunis (blog). October 27, 2018. https://twitter.com/willisfromtunis/status/1056204735047483392. 
Zinn, Dorothy Louise. 2001. La raccomandarione: clientelismo vecchio e nuovo. Donzelli Editore. 